\title{
Strengthening Character Education(PPK)Policy Through Five School Days in Gresik Regency (Study on Implementing of Strengthening Character Education(PPK) Middle School Policy)
}

\author{
Taufiq Harris $\quad$ Arif Darmawan Endro Tjahjono \\ Doctoral Administration Study Program Faculty of Social and Political Sciences \\ 17 Agustus 1945 University of Surabaya. Semolowaru 45 street, Surabaya
}

\begin{abstract}
The purpose of this study was to described and analyzed the implementation of the policy on strengthened character education(PPK)through five school days in Gresik Regency, then the supported and inhibited factors of the internal and external environment of the school in implemented the policy on Strengthened Character Education(PPK)) through five school days in Gresik Regency, and also, the impact of implementing the policy of strengthened character education(PPK)through five school days in Gresik Regency. This research used qualitative methods and types of descriptive research. Data collection techniques used semi-structured interviews, observation, and documentation. Data were analyzed using interactive model data analysis. To obtained the validity of the data, researchers used a source of triangulation and triangulation technique. The results of this study indicated that the implementation of the policy for strengthened character education(PPK)through five school days in Gresik Regency has been well implemented through the stages of the communication process with indicators of transmission, clarity, and consistency. Resources included teachers, staff, budgets, facilities/infrastructure supplied quality and quantity, as well as sufficient information and authority to carry out their duties and responsibilities. Then the attitudes and commitments of the teachers and all elements of the school carried out seriously with a bureaucratic or organizational structure that is equipped with Standard Operating Procedures $(S O P$ ) that were easy and clear, and the social, economic and political environment runs effectively. Internal and external supported factors were interrelated in helping the implementation of effective policy implementation. While internal and external inhibited factors found insignificant obstacles, resulted in an increase in the quality of education process services in schools that lead to the fulfillment of National Education Standards(SNP), especially in the learning process found a dominant result and an important role for education was the learning process proportional to the realm of cognitive, psychomotor, affective, and the absence of tracking in schools, the impact of positive changed for schools, families/guardians of students and the community.
\end{abstract}

Keywords: implementation of strengtheningcharacter education (PPK)policy, school for five days, junior high school.

DOI: $10.7176 / \mathrm{PPAR} / 10-1-04$

Publication date: January $31^{\text {st }} 2020$

\section{INTRODUCTION}

Law Number 20 of 2003 concerning the National Education System, in general terms article 1 paragraph (1), (2) and Article 3, mandates that the substance of character education must be developed to achieve national education. The mandate was outlined by the government of Joko Widodo and Yusuf Kalla from 2014 to 2019 in the eighth Nawa Cita program which focused on the character itself and character building for students as part of the National Mental Revolution Movement (Gerakan Nasional Revolusi Mental (GNRM)) and became a priority program of education and culture. The government conducts restoration of character education through the policy of the Minister of Education and Culture Regulation No. 23 of 2017 concerning School Days, the substance of which is to change the policy of the number of days of study at school from six days to five days, teaching and learning activities in schools need eight hours a day which starts from Monday to Friday, the additional hours can be used for character development activities instead of adding subjects.

The issuance of Minister of Education and Culture Regulation No. 23 of 2017 concerning Schools raises pros and cons among education observers and the community, one of which is the most opposing in all regencies / cities in Indonesia, and asks President Joko Widodo to request Minister of Education and Culture Regulation No. 23 of 2017 concerning School Day. The polemic ended, after President Joko Widodo released Presidential Regulation No. 87 concerning Strengthening Character Education(PPK)so that Minister of Education and Culture Regulation No. 23 of 2017 concerning School Days no longer applies.

Presidential Regulation Number 87 of 2017 concerning Strengthening Character Education (Penguatan Pendidikan Karakter (PPK)) is broader and more flexible about school days, it is so supportive, schools can choose to use five days or six school days in renewal. Regional Regulation Number 87 of 2017, article 9 paragraph (1), states " The Implementation of Strengthening Character Education(PPK)in Education Units lines 
approved by Article 6 is carried out for 6 (six) or 5 (five) school days in 1 (one) week ". And Article 9 Paragraph (2) about "The provisions of the school day approved in paragraph (1) are given to each Education Unit together with the School / Madrasah Committee and support the Regional Government or ministry offices that assist government affairs in each field ". Then article 9 paragraph (3) is stated, "In the agreed 5 (five) school days approved in paragraph (1), the Education Unit and School / Madrasah Committee consider a. the adequacy of educators and education personnel; b. allocated infrastructure and facilities; c. local wisdom; and D. the opinions of community leaders and / or religious leaders outside the School / Madrasah Committee ".

Furthermore, the implementation of Strengthening Character Education(PPK)in Presidential Regulation Number 87 of 2017, Article 6 paragraph (1), states " The implementation of strengthening character education (PPK) in the Educational Unit for Formal Education, as referred to in Article 4 letter a number 1, is carried out in an integrated manner in the activities of: a . Intrakurikuler; b. Kokurikuler; and c. Extracurricular. Then the implementation of the learning activities referred to in article 6, paragraph (1) requires sufficient time, giving rise to various challenges for schools to have the ability to make a time management design because the implementation of PPK integrally requires learning planning to completion of the assessment. Therefore in Article 6 (six) explains," PPK in the education unit of the formal education pathway as referred to in paragraph (1) is implemented with the principle of school/madrasah based management ". This is in line with Government Regulation Number 32 of 2013 concerning National Education Standards in article 49, paragraph (1) stated that " Management of education at the level of primary and secondary education implements school-based management as demonstrated by independence, partnership, participation, openness, and accountability". In principle, School-Based on Management(MBS)gives authority to the education unit, namely the principal, teachers, and is assisted by the school committee, so that the school is able to independently manage resources, make decisions to carry out various strategies, approaches, practices to make school models, even add the duration of school time in implementing the strengthening of character education(PPK). Essentially the principle of School Based on Managemen(MBS)encourages education units as inspirators, communicators and designs collaborative roles of schools, parents, communities in strengthening the implementation of classroom-based on PPK, school-based on PPK, community-based on PPK, including making changes in management changes to increase the quality of education.

At the beginning of the interview, researchers found the importance of increasing the duration of time in the process of teaching and learning activities in schools or through five school days in one week or eight hours a day to cover three learning activities; proportional intracuricular, co-curricular and extracurricular activities such as designing time management implemented by dividing time stations; 06:30 to 8:30 is the Spiritual Quation time. And from 08:30 to 14:00 is the Regular Class station time (complete with national curriculum). Then from 2:30 p.m. to 4:00 p.m. is the Moving Class time namely; extracurricular activities are a place to develop children's interest talents and where students channel their fun. If it does not add to the duration of time, it cannot optimize learning activities especially extracurricular activities, meaning that extracurricular activities cannot be implemented equally for students. The problem is for schools that have not applied the five-day school concept because they are not ready to make adjustments to resources, especially budget resources, and infrastructure resources.

The development of the management of the state elementary school level(SDN)and the state junior high school(SMPN)in Gresik Regency has not implemented the strengthening of character education(PPK)through five school days in one week or 8 hours a day, but the implementation of school time in Gresik Regency optional for private schools, can choose 5 (five) or 6 (six) school days in one week. In this study, researchers are interested in junior high schools(SMP)who have carried out strengthening of character education through five school days in accordance with Presidential Regulation No. 87 of 2017, in Article 16, paragraph (2) states. " Formal Education Unit that has implemented PPK through 5 (five) school days that existed before the entry into force of this Presidential Regulation is still ongoing ". Considerations made by researchers, because the school has long held a strengthening of character education that integrates intracuricular activities, curricular activities, and extracurricular activities through five school days in 1 (one) week or 8 hours a day.

Preliminary studies conducted by researchers from 112 junior high schools (33 public junior high schools and 79 private junior high schools) in Gresik Regency, which are in accordance with Presidential Regulation Number 87, article 16, paragraph (2), researchers obtained two schools namely; YIMI SMP Full Day School and Muhammadiyah 12 Manyar Gresik Middle School. And apparently, both of them are favorite schools in Gresik Regency.

Based on the above explanation, and taking into account the policy objectives of the Regulation of the Minister of Education and Culture number 23 of 2017 concerning school days revised by Presidential Regulation Number 87 of 2017 concerning Strengthening Character Education(PPK)is a public policy. As written by Riant Nugroho (2008: 55) Public policy is a decision made by the state, specifically the government, as a strategy to realize the objectives of the country concerned. Public policy is a strategy to take the community at an early stage, entering the community at a time of transition to the aspired society ". Then see the role of the education 
unit as a forum to develop the potential of future generations in printing Indonesian people with character. While there are still many problems regarding the assumption that the five-day school is a hasty policy, forced, burdensome teachers and students and is still controversial. And the answer to the Presidential Regulation Number 87 of 2017, that the implementation of strengthening character education (PPK) in the education unit can be carried out is optional, namely for 5 (five) days or 6 (six) days there are still many that have not been satisfied. Then this research was conducted hoping to find out the reality and find the quality of strengthening character education (PPK) policy implementation through five school days to provide solutions and answers to schools, families, and the community.

\section{MATERIALS AND METHODS}

The success of achieving the policy of strengthening character education(PPK)through five school days in Gresik Regency depends on how the policy of strengthening character education(PPK)is implemented. Therefore to achieve effective and efficient results which then have an impact on schools, families, and communities, it is necessary to identify the factors that support and hinder the implementation of the policy of strengthening character education(PPK)through five days in junior high schools in Gresik Regency.

By the background that has been described, the research questions to be examined are as follows: 1)How is the implementation of the policy to strengthen junior high school character education through five school days in Gresik Regency, now? 2) What are the factors that support and hinder the implementation of policies to strengthen junior high school character education through five school days in Gresik Regency? 3) What is the impact of implementing the policy of strengthening junior high school character education in Gresik Regency?

\section{Public Administration}

According to Pfifner and Presthus (Riant Nugroho, 2008: 90), public administration is an activity relating to the implementation of public policies that have been made previously by political representative institutions. So public administration can be defined as the coordination of individual and group efforts to carry out meaningful public policies concerning the daily activities of a government. While Amin Ibrahim (2013: 15-17) reveals administration / public administration covers all efforts of government administration which include government management activities with work mechanism and human resource support as well as administrative or administrative support. As written by Sjamsuddin (2006: 116) public administration tries to institutionalize management practices to fit the value of effectiveness and efficiency in better meeting the needs of the community.

Thus, public administration is the view of various scientific disciplines that represent all activities related to the administration of government processes. And one of them is Presidential Regulation number 87 of 2017 concerning Strengthening of Character Education(PPK).

\section{Public Policy and Character Education Policy}

Riant Nugroho (2008: 53-54) reveals that there are many definitions of public policy as formulated by Harold Laswell and Abraham Kaplan (1971). David Eston (1965: 212). James Anderson (2000: 4). James Lester and Robert Steward (2000: 18). Austin Ranney (quoted by Lester \& Steward, 2000: 18). Steven A. Peterson (2003:: 1030) government action to address some problems. B.G. Peters (1993: 4). Carl I Friedrick (1963: 79. So many definitions of public policy, but all of them are true and complementary. Next is Riant Nugroho (2008: 55) defines that public policy is a decision made by the state, specifically the government, as a strategy to realize the goals of the state. Meanwhile, according to Mulyadi (2015: 3), public policy is a process of formulation, implementation, and evaluation of policies that are continuous and interrelated, carried out by the government and stakeholders in regulating, managing and resolving various public affairs, public problems, and resources available for public safety. Then Joko Widodo (2017: 14) explains, the purpose and objectives of public policy made by the government are to solve public problems that are developing in society, so the issuance of Presidential Regulation number 87 on Strengthening Character Education(PPK)to solve educational problems in the field of education national character education. As written by Rusdiana, A, (2015: 37) education policy is an amalgamation of the words education and policy. The policy is a set of rules, while education shows in its field. Whereas Hasbullah (2015) explains that education policy concerns the interests of the public which are both extensive and comprehensive. Then H.A.R. Tilar and Riant Nugroho (2008: 264) define education policy as part of public policy.

Character education has become an inseparable part of efforts to achieve the vision of national development contained in the long-term plan for 2005-2025 (Muchlas Samani and Hariyanto, 2016: 27). The role of character education in national policy is a priority goal for the development of the nation's generation, especially through the education unit. Same with the opinion of Stopplewort (2001) quoted by Miller, Johncarlos M (2016: 41). Character education is a broad term used to describe society's efforts to transmit and instill values from preceding to succeeding generations. 
Thus, the policy of Presidential Regulation number 87 on Strengthening Character Education(PPK)is public policy as a series of policy decisions taken by a person or group of people to realize certain goals in society.

\section{Public Policy Process}

The policy process goes through several stages, according to Thomas R, Dye (1992: 328) quoted by Joko Widodo (2017: 16-17), namely (a) identification of policy problems, (b) agenda-setting), (c) policy formulation , (d) legitimating of policies, (e) policy implementation, (f) policy evaluation. It can be seen that each stage of the policy process has activities. In this study regarding the stages of policy implementation namely; The implementation of Presidential Regulation number 87 of 2017 concerning Strengthening of Character Education, relates to who is involved in the implementation, what must be done so that the implementation of the Presidential Regulation can have an effect and what impact on the policy content of the Presidential Regulation.

\section{Public Policy Implementation Model}

Public policy studies in the Public Policy book by Riant Nugroho (2008), can be found in various models of implementation, including models of the implementation of public policy Donald Van Meter and Carl Van Horn (1975), Mazmanian and Paul A. Sabatier (1983). Model Brian Hogwood and Lewis Gunn (1978). The model of Malcolm Goggin, Ann Bowman, and James Lester (1990). The Merilee S. Grindle Model (1980). Model Richard Elmore, et al. (1971 \& 1981). Model of George Edward III (1980). Nakamura \& Smallwood models.

Based on the consideration of the phenomenon in the implementation of the policy of strengthening character education(PPK)through five school days in Gresik Regency, researchers used a combination of theories by choosing two models of policy implementation with a top-down perspective, including four factors developed by George C. Edward III, by naming the implementation model public policy is direct and indirect impact on implementation (Edward III in Agustino, 2016: 136). Does the Edward III policy implementation model start with two questions, namely (1) What is the precondition for successful policy implementation? (2) What are the primary obstacles to successful policy implementation? The purpose of these two questions is to see what factors are as prerequisites or supporters and obstacles to the success of policy implementation. Then, from these two questions, four main issues were formulated to become a concern so that the implementation of the policy could run effectively, namely: communication, resources, disposition or attitudes, and bureaucratic structures. (Nugroho, 2014: 673). (Edward, 1980). And one economic, social and political environmental factor developed by Donald Van Metter and Carl Van Horn, namely the top-down and linear model of policy implementation, means that policy implementation must be by established policies (Tachjan, 2006: 40). (R. Nugroho, 2008: 503). Choosing one factor developed by Donald Van Metter and Carl Van Horn, namely the economic, social and political environment in implementing the policy of strengthening character education(PPK)through five school days in Gresik Regency, because the implementation of the PPK movement is a joint responsibility between the government, the education unit, school committee, parents and community.

According to M. Ngalim Purwanto, (2008: 188), schools and communities are one of the fields of education administration. And schools cannot be separated from the community or schools are social institutions that function to serve the community, in simple terms schools are an integral part of the community. Even the economic capacity of the community or family, local government support related to schools, especially in the availability of school resources to support the quality of education. So the implementation of character education strengthening(PPK)must collaborate with the community.

Therefore, the success and failure of implementing character education strengthening(PPK)through five school days in the Gresik Regency cannot be separated from the influence of economic, social and political environmental factors as supporters or inhibitors.

\section{Framework of thinking}

The policy to strengthen character education(PPK)which revised the Minister of Education and Culture's policy on school days, was the government's decision to solve the problems of national character education involving education units, families and communities as part of the National Mental Revolution Movement(GNRM). While the policy of strengthening character education(PPK)which provides an optional implementation of strengthening character education (PPK) can be carried out for 6 days or 5 days, many are still unsatisfied, even there are many assumptions that the five-day school is a hasty and forced policy, especially increasing the burden on teachers and students. But the fact is that many parents are interested in sending their children to schools that stipulate the implementation of strengthening character education (PPK) for five days a week. Therefore, this research is an effort to explain and provide information about the benefits, impacts, and constraints in implementing the policy of strengthening character education through five school days in Gresik Regency. And this research study, researchers used a combination of theory studies, including four theories of the policy implementation of Edward III namely; communication, resources, disposition, bureaucratic structure, and one factor of Van Metter and Van Horn namely; economic, social and political environment. These five 
factors are seen to influence the successful implementation of the policy on strengthening character education(PPK)through five school days in Gresik Regency. These five factors are interrelated between one factor and the others and if they run synergistically they will achieve the objectives of the strengthening character education (PPK) policy. In Edward III the factors of implementing the policy of strengthening character education(PPK)through five school days in Gresik Regency, are as follows:

Communication is an important criterion in implementing the policy of strengthening character education(PPK)through five school days in Gresik Regency. It can be known from the communication side by using indicators; transmission, clarity, consistency. (Winarno, 2014: 178), (Widodo, 2017: 97), in the implementation of classroom-based on PPK, school-based on PPK and community-based on PPK involving school communication with parents, school committees, business world, academics, education tips/community leaders, Gresik Regency government/education office. Starting from the preparation of the School Work Plan(RKS)that includes the Medium-Term Work Plan(RKJM), Annual Work Plan(RKT), and School Budget Work Plan(RKAS)as a guide to implementing quality fulfillment that is carried out for the preparation of developing 8 national education standards through In this communication process, PPK implementers or all elements identified in the bureaucratic/organizational structure get clear about the substance of strengthening character education (PPK policies including the objectives, targets, and direction of strengthening character education (PPK) policies.

By understanding the substance of strengthening character education (PPK)policies, it will be easier to develop a Standard Operating Procedure (SOP) as a dimension of the school organizational structure. And the clarity of the substance of strengthening character education (PPK)policies and SOPs in organizing PPK made the disposition of the implementers/teachers clearer so that the implementers/teachers were receptive and had an attitude of supporting the implementation of strengthening character education (PPK) policies.

Then through the intensity and effectiveness of this communication, the resources which include teachers and staff/staff, school budgets, school infrastructure, information, and authority as well as the needs needed in the implementation ofstrengthening character education (PPK)are more easily determined. And this requires the role of the principal who is capable and professional during the PPK policy implementation process.

The bureaucratic/organizational structure, as stated earlier, includes the distribution of authority, and organizational relationships such as intra and extra relations in the implementation of strengthening character education (PPK) policies. In the dimensions of school organizational structure, it is divided into two, namely the dimensions of fragmentation and the dimensions of Standard Operating Procedures (SOP) affecting the level of intensity and effectiveness of the communication of the implementation of strengthening character education (PPK)policy. The more fragmented the school's organizational structure, the more it requires intensive coordination and does not rule out the possibility of communication distortion. If there is a distortion of communication in the implementation of strengthening character education (PPK)policy, there is a chance that the implementers/teachers/ school elements will not understand the knowledge, depth, and understanding of the substance of strengthening character education (PPK) policy, as a result, the greater failure of the implementation ofstrengthening character education (PPK) policy.

Likewise, the clearer and easier the SOP is, the easier it will be to determine the quality and quantity requirements for strengthening character education (PPK) policy implementation resources. And the accuracy of the implementer/teacher in determining the resources needed is an opportunity for the successful implementation of strengthening character education (PPK)policies. Conversely, the limited resources needed by the implementers/teachers will lead to a failure in the implementation of strengthening character education (PPK) policies.

The structure of the bureaucracy/school organization influences the disposition of the implementers/teachers, because the more the organizational structure of the school is fragmented, the implementers/teachers the greater the chance of conflict, so the relationship between the implementers/teachers is not harmonious, this results in different dispositions of the implementers/teachers in PPK policy implementation. The implication is the failure of PPK policy implementation. SOPs of implementers/teachers also influence the level of disposition, the more clearly SOPs will make it easier for implementers/teachers to understand the substance and direction of policies which include; objectives, target groups and know the benefits of what impacts are achieved and produced by the teachers / implementing policies and schools. This clarity will improve school disposition and organization in implementing PPK policies. And the high disposition of school implementers and organizations will provide an opportunity for successful implementation of PPK policies.

Furthermore, social, economic and political environmental factors influence the communication side in the implementation of policies for strengthening character education(PPK)through five school days in Gresik Regency, seen in the preparation of school work plans(RKS)that contain medium-term work plans(RKJM), work plans annual budget(RKT)and school budget work plan(RKAS)as a guideline for the implementation of quality fulfillment conducted for the development of eight national education standards. Through the process of policy transformation by involving elements of the school, community, and the government has the opportunity to get a 
clear clarity of the substance of strengthening character education (PPK) policy, including the goals, objectives, and direction of PPK policy, it can be accepted by all elements, especially the target groups. The appropriateness of clarity of the substance of the policies of the implementers/elements of the school with the social, economic and political environment will affect the efficient dimensions of the school organizational structure, especially in preparing SOPs for the relationship between schools and organizational elements outside the school. And this makes the level of disposition of the implementers/elements of the school have the motivation and attitude to support the implementation of strengthening character education (PPK) policies so that the availability of resources needed in the implementation of strengthening character education (PPK) policies is easily met. The synergy in the social, economic and political environment with communication, resources, disposition, and bureaucratic structure will support the implementation of strengthening character education (PPK) policies. Otherwise, the opposite would be an obstacle to the implementation of the strengthening character education (PPK) policy.

\section{Research Methods}

This research focuses on implementing the policy of strengthening character education(PPK)through five school days in Gresik Regency. This study uses a qualitative approach as a research procedure that produces descriptive data. This approach was chosen because what was studied involved the social sphere, which was tentative, and temporary that required direct observation in the field. Bogdan and Taylor (1975), explain a qualitative approach as a research procedure that produces descriptive data in the form of written words from people and observable behavior (Moleong, 2012: 4). According to Bogdan and Biklen (Sugiyono 2015: 40), that the qualitative approach is descriptive. Data collected in the form of words or pictures, so it does not emphasize numbers. Meanwhile, according to Afifuddin and Beni, A. S (2009: 102), the problem in qualitative research is tentative, and temporary, because the questions will develop depending on the reality of the field when researchers conduct research activities.

The locus of this research was determined purposively in Gresik Regency namely YIMI Middle School "Full Day School" and Muhammadiyah Middle School 12. Data sources in this study were educational foundations, school principals, head of school affairs, homeroom teachers, students, guardians of students, school committees, leaders community, education office. The key informant is the principal, then determined through snowball to the level of redundancy. Purposive sampling is a technique for taking data sources based on specific objectives or considerations (Sugiyono, 2015: 368). Data collection techniques used in this study were semi-structured interviews, observation, and documentation. While the data analysis technique uses an interactive model proposed by M.B. Miles., Huberman and Saldana, J. (2014: 33), namely; data condensation, data display, and conclusion drawing/verification. The results of the data analysis are verified by extending the observation, source triangulation, and technique triangulation.

\section{RESULTS AND DISCUSSION}

\section{Implementation of Strengthening Character Education (PPK) Policy}

Through Five School Days in Gresik Regency. The process of implementing the policy of strengthening character education (Penguatan Pendidikan Karakter (PPK)) through five school days centers on the following dimensions: (1) Communication. (2) resources. (3) disposition. (4) bureaucratic/organizational structure. (5) Social, economic and political environment.

\section{Communication}

Implementation of the policy on strengthening character education(PPK)through five school days in Gresik Regency, the first step of the Gresik District Education Office invited the school principal to conduct socialization in the form of a coordination meeting to understand the essence, objectives, direction and target groups of the policy on strengthening character education (PPK). Furthermore, the Office of Education conducts socialization according to the needs of the level of socialization of the implementation of strengthening character education (PPK) in the form of bintek, workshops, seminars and training with inviting all elements of the school concerned.

The next step, the headmaster conducts internal and external socialization in the form of meetings or joint meetings with teachers, school committees, foundations, and stakeholders by compiling a school work plan (RKS)that includes a medium-term work plan(RKJM)adjusted to the strategic plan(Renstra)local education office. Then the headmaster conducts internal socialization through a coordination meeting with the teacher in charge of strengthening character education, subject teachers and school committees to prepare an annual work plan(RKT)stated in the work plan and school budget(RKAS). Internal and external socialization is carried out as a program to strengthen character education(PPK)which contains the eight of national education standards(SNP).

Furthermore, the school principal conduct socialization with implementers / teachers through curriculum communication that includes strengthening of character education(PPK)on content standards including; syllabus, 
lesson preparation plan(RPP), assessment, core competency 1 and core competency 2 include character education and social aspects, as well as ensuring the strengthening of character education is integrated in all subjects and local content, while ensuring remedial program documents, enrichment programs, semester programs and documented annual programs. After that the principal and senior teachers strengthen the socialization through standard communication processes with clinical supervision and classroom supervision to ensure the implementation of the reinforcement of character education(PPK)is by the content standards, this is done every three months. The next stage, the headmaster conducts socialization through communication of graduate competency standards(SKL)to the implementers / teachers, students, committees, student guardians and stakeholders in the form of daily activities, meetings, meetings and deliberations of subject teachers(MGMP)held every day, every week, every month and every year (scheduled) at school. Even the principal provides time for socialization in the form of incidental communication to oversee the implementation of the character education strengthening program(PPK)that has been determined until the end of the program. After that, the headmaster and the teachers will conduct socialization through the communication of assessment standards in the form of meetings and reports to parents, education offices and foundations which are conducted every three months, six months and annually.

Thus, communication of the implementation of the policy on strengthening character education(PPK)through five days in Gresik District has carried out a transformation process for all elements of schools, implementors, communities, and the local education office. Clarity and consistency of socialization in the form of coordination meetings, bintek, workshops, seminars and training and communication at each national education standard(SNP), so that all elements involved, especially implementers/teachers and target groups become clear what the objectives are, policy goals and direction. According to Edward III, effective implementation occurs when decision-makers already know what they are going to do (Agustino, 2016: 136), then communication through three indicators to measure the success of communication factors, namely transmission, clarity, consistency (Agustino, 2016: 136- 141). (Winarno, 2014: 178). (Widodo, 2017: 97). Based on this theory, it can be explained, communication in the implementation of the policy of strengthening character education(PPK)through five school days in Gresik Regency is going well according to existing theories.

\section{Resource}

Resources have an important role in implementing the policy of strengthening character education(PPK)through five school days in Gresik Regency. According to George C. Edward III quoted by Widodo (2017: 98), and Agustino, (2016: 136-141), explained that in implementing policies, indicators of resources consist of several elements, namely: human resources/staff, resources financial/budgetary resources, equipment/facility resources, and information resources and authority have an important role as an effective policy implementation.

a) Human resources

The aspect of human resources in implementing the policy of strengthening character education(PPK)through five school days in Gresik Regency, in quantity has met well that is the number of implementers/teachers needed is sufficient, as well as the quality (expertise) of the implementers have expertise and ability in accordance with the main tasks and functions. The executors of the bachelor's degree and several strata 2 molarity implementers. According to Edward III, quoted by Widodo, (2017: 99), explained the limited human resources in terms of quantity and quality, the implementation of policies would not be effective. Even so, to obtain the effectiveness of the implementation of the policy does not only rely on the number of human resources but must have the skills needed to carry out the duties and functions that are its responsibility. Thus and based on theory, the researcher concludes that human resources in implementing the policy of strengthening character education(PPK)through five school days in Gresik Regency have met the needs, accuracy, and feasibility, so there are no problems with human resources/staff.

b) financial / budget resources

Budget resources in implementing the policy of strengthening character education(PPK)through five school days in Gresik Regency, the source of the budget comes from student guardians or students who are managed directly by the foundation and sent down to the school for operational implementation. The source of the annual budget is determined through several analyzes, which are conducted by the principal, senior teachers, and the person in charge of the activity, then an analysis of the two foundations with the principal and the school treasurer is determined by the foundation. Determining school budgets is always carried out comparative studies and feasibility studies by taking into account the operational needs of the school and taking into account the economic conditions of the community. And there is a source of the government budget, namely the school operational assistance budget (BOS), and funding assistance from outside the school in collaboration with schools / social institutions outside the school, such as Lazismu, and managing other business divisions. Under these conditions, the researcher concludes the findings that the budget resources for implementing character educationstrengthening policies through five school days in Gresik Regency meet the operational needs of PPK policy implementation, so that all activities can be carried out effectively. As explained by Edward III, quoted by 
Widodo (2017: 100). The effectiveness of the implementation of policies other than human resources is the budget resources needed to finance the operationalization of policy implementation. So based on the theory, the implementation of strengthening character education (PPK) policy through five school days in the Gresik Regency was effective from the aspect of budgetary resources.

c) equipment / facility resources

The resources for implementing the character education(PPK)strengthening policy through five school days in Gresik Regency, including buildings, land, facilities, and infrastructure, including information technology, have all been fulfilled as supporting tools and can provide motivation and support services to implementers and all parties which are involved. Researchers' findings on equipment resources that the school has a contextual team that coordinates with the principal and implementers, the team is under the instruction of the chief executive staff of the foundation's activities, its task is to maintain and to inventory the condition of the equipment resources, so that the available facilities can always support implementation Policy. According to Edward III (1981: 11), that equipment resources are infrastructure facilities used for the operationalization of the implementation of a policy that includes buildings, land, and facilities that all facilities in providing services in policy implementation (Widodo, 2017: 102). Thus, it has been available and meets the needs of facilities and equipment for the implementation of policies to strengthen character education(PPK)through five school days in Gresik Regency. d) Information resources and authority

information resources and authority in implementing the policy of strengthening character education (PPK)through five school days in Gresik Regency, it can be seen that the implementers/teachers carry out the implementation of the strengthening character education (PPK) policy in accordance or relevant in a specified manner. And schools have the authority in implementing PPK policies, as well as the implementers/teachers have the authority according to their duties and responsibilities to solve problems and make decisions. According to Edward III (Widodo, 2017: 102) relevant and sufficient information about relating to how to implement a policy. While authority is needed, especially to guarantee and ensure that the policies to be implemented are by what they want. Based on the theory of implementation, it can be concluded that information resources and authority in implementing the policy of strengthening character education(PPK)through five school days in Gresik Regency run well and by the aims and objectives to be achieved.

\section{Disposition}

Researchers obtained findings that the implementers and all those involved have knowledge, understanding and deepening of the substance of the policy of strengthening character education (PPK)through five school days, this can be known from several indications namely the number of training and development frequencies organized by schools in various forms PPK workshops and models of meetings, such as in-house training and external house training, leadership training, parenting seminars involving all parties, religious activities, managerial meetings. These various training and developments are to motivate and strengthen the commitment of the implementers and all parties involved. Then the other indications are the implementers or teachers in carrying out their main tasks and functions prioritizing service in the form of services to students and being able to be together with student guardians, foundation school committees, education offices and to the community, obediently carrying out their obligations both in nature instructions as well as those which are his duties and responsibilities. Findings in an interview with a curriculum teacher (the US, 38 years) explain, the implementers serve students and guardians of students in implementing the policy of strengthening character education(PPK)without any time limit, meaning that anytime the implementers will respond. According to Edward III (1980: 11)), policy implementation is successful effectively and efficiently, the implementers not only know what needs to be done and have the ability to carry out the policy, but they must also have the will to implement the policy (in Widodo, 2017: 104). Thus, the disposition in implementing the policy of strengthening character education(PPK)through five school days in Gresik Regency has an attitude of support and runs well.

\section{Bureaucratic / Organizational Structure}

The researcher looked at the school organizational structure in implementing the implementation of the policy on strengthening character education(PPK)through five school days in Gresik Regency using Standard Operating Procedures (SOP) that have been established as guidelines for implementation and in accordance with the mechanisms that are the task, principle and function, authority and responsibility the answer. The procedure is simple, facilitates the actions of the implementers and guarantees the implementers to be able to make a decision, especially to solve the problems that become their area of work. In addition, the implementers and all parties involved coordinate with each other, work together, form harmonious relationships with each other, so there is no problem of communication distortion, instead strengthen the intensity of disposition, facilitate the availability of resources in the implementation of strengthening character education (PPK) policy implementation, the same as what is explained by Edward III namely there are two characteristics to drive the performance of bureaucratic or organizational structures in a better direction, first; make Standard Operating Procedures (SOP) more flexible, 
secondly; fragmentation is the spread of responsibility in various activities in several work units in accordance with their respective fields, so that the implementation runs effectively, because it is carried out with competent and capable people. (Agustino, 2016: 206). Similarly, the opinion of Widodo (2017: 106) bureaucratic structure includes diminishing fragmentation so that implementation is effective because it is carried out with people who are competent and capable. Standard Operating Procedures (SOP) that will facilitate and uniform the actions of the implementers of policies in carrying out what is their area of duty.

Thus, it can be concluded from the results of research that the structure of the bureaucracy or organization in implementing the policy of strengthening character education(PPK)through five school days in Gresik Regency has been going well.

\section{Social, Economic and Political Environment}

Social, economic and political aspects are factors that can influence the success and failure of implementing character education(PPK)strengthening policies through five school days in Gresik district, which are directly related to the conditions of the people of Gresik Regency. According to Donald Van Metter and Carl Van Horn quoted by Winarno (2014) social, political and economic conditions also influence the implementation of a policy. Likewise, the opinions of Donald Van Metter and Carl Van Horn in Subarsono (2011: 99) Nonconducive social, economic and political environment can be a failure in policy implementation.

Researchers search results, in the economic realm of the Gresik community related to the implementation of the policy of strengthening character education(PPK)through five school days there are no significant problems, because schools are able to help solve problems to ease the burden on parents who are in a weak economic condition through several programs School collaboration with foundations, student guardians, and third parties, such as with social institutions, even if deemed necessary does not rule out the possibility of joint district education offices. While the social benefits can be felt especially for the guardians of students and the community, this indication can be seen, that there have been a number of private junior high schools (Private Junior High Schools) changing their management to five school days, although there are still obstacles from the environment regarding the completeness of students in the process of strengthening character education which is still influenced by the environment outside the school. While politically, the Gresik community has been able to accept, because there is conformity to the conditions, potential, and values of the regional characteristics of the implementation of the policy of strengthening character education(PPK)through five school days in Gresik Regency, this is inseparable from the support and efforts of the delivery process information by the Gresik Regency education office, foundations, school principals, teachers and all parties involved in providing a policy understanding on strengthening character education(PPK)through five school days.

Thus, it can be concluded that social, economic and political conditions in the implementation of the policy on strengthening character education (PPK)through five school days in Gresik Regency are going well and by the existing implementation theory.

\section{Supporting and Inhibiting Factors for Implementing Character Building Strengthening Policies (PPK) through Five School Days in Gresik Regency.}

To find out the factors that support the implementation of the policy of strengthening character education(PPK)through five school days in Gresik Regency, viewed from two dimensions, the first is from the internal dimension namely; the intensity of strengthening character education (PPK) socialization to all elements of the school, strong commitment and willingness of all elements of the school, easy and flexible SOP, adequacy of educators and education personnel in quality and quantity, availability of facilities, fulfilled budget / financial resources as needed. And, the second dimension from the external namely; the commitment of the Gresik Regency Education Office to provide assistance to schools through school supervisors, including BOS assistance, strong caring attitude from students' parents in character education activities inside and outside of school, the participation of the community and community leaders who are directly involved in PPK activities. The inhibiting factor is also seen from two dimensions, the first is the internal dimension namely; two teachers (out of 96 teachers) who lacked consistent policy implementation. then the students were not yet able in the first school year to make adjustments to the school habituation program. And the second dimension from the external is only one problematic child, which is caused by the parents of students having family problems, so that the child is easily formed by the outside environment, but this does not become a significant obstacle for the implementation of strengthening character education (PPK) policies, and from the results of interviews, this obstacle was only done by one child in the 2018/2019 school year.

\section{The Impact of the Strengthening of Character Education (PPK) Policy Through Five School Days in Gresik Regency.}

The implementation of the policy on strengthening character education(PPK)through five school days in Gresik Regency, increases the quality of education quality services leading to the national education standard (Standar 
Nasional Pendidikan (SNP)) received by students/target goals and the impact of positive changes in schools, family and community. The three elements, namely schools, families, and communities are the target groups as stated in Presidential Regulation number 87 regarding the strengthening of character education(PPK). Article 1, paragraph (1) and regulation of the minister of education and culture number 20 of 2018 concerning the strengthening of character education in formal education units. In Article 5, paragraph (1) which means that PPK is held in an educational unit involves these three elements as a function of the education trip center partnership, namely schools, families, and communities. Therefore PPK policy is an activity to produce (outputs), impacts that can be felt by schools, families, and communities. According to Widodo (2017: 88). Public policy implementation is an activity to produce (outputs), impacts that can be enjoyed by the target goals.

And also, there are other impacts that cause some real changes to schools, namely; revitalizing school-based management, schools having a conducive environmental ecosystem, fulfilling school resources in accordance with the needs of national education standards, schools getting good relations from parents, community /institutions/education activists, and education offices, schools have comprehensive curriculum, no tracking (new school paradigm). Then the impact on the family is; parents better understand their role in the child's personality, parenting parents are in harmony with those applied at school, parents are helped in educating the character of children at home, parents know good school conditions and the character of the teachers. And the impact on society namely; strengthen noble values, able to maintain habits or values, behavior in society. the synergy of various PPK programs with the community component, encouraging schools to have the potential to meet national education standards, the public receives quality education services in the global era to prepare graduates to enter senior high school evenly.

\section{CONCLUSION}

Based on the discussion and research that refers to the purpose of the study, conclusions can be formulated as follows:

1. The implementation of the policy to strengthen character education(PPK)through five school days in Gresik Regency is running effectively. due to the fulfillment of the prerequisites for implementation, including the existence of communication that is carried out properly through the dimensions of transformation, clarity, consistency, and support of resources, especially human resources, financial resources, equipment/infrastructure resources, information resources and authority that are adequate. Implementers/teachers and all stakeholders have a strong disposition towards the implementation of PPK policies. Bureaucratic or organizational structure is by Minister of Education and Culture Regulation number 6 of 2019 concerning organizational guidelines and work procedures of primary and secondary education units developed using school-based management supplemented by flexible standard operating procedures (SOP). The social, economic and political environment has a positive effect, because according to presidential regulation number $87 \mathrm{PPK}$ is organized by schools involving families / guardians of students and the community, with the role of the principal and teachers, school committees, foundations, local education offices, then social, economic, and politics can work together in implementing PPK policies.

2. Supporting factors from internal and external school institutions where situations and abilities that are positive are the ability to overcome internal and external obstacles that are not important so that the implementation of the policy of strengthening character education(PPK)through five school days in Gresik Regency runs effectively according to which is expected. The dominant internal supporting factor lies in the communication or intensification of PPK socialization to all elements of the school, strong commitment and willingness from all elements of the school, the existence of easy and flexible SOPs, the adequacy of education and education personnel in quality and quantity, availability of facilities that meet needs, fulfilled budget / financial resources as needed. Then the deciding factor of external support is the commitment of the Gresik District Education Office to assist schools through school supervisors, including BOS assistance. a strong caring attitude from students' parents in character education activities inside and outside the school, the participation of the community and community leaders who are directly involved in PPK activities. While the inhibiting factors from internal are only two teachers (out of 96 teachers) who are less consistent, then students in the new school year who have not been able to adjust the habituation program, these two internal barriers are very insignificant, as well as external school barriers do not become obstacles that are means, because of all students who formed the environment (problematic parents and outside the home environment) only found one person each year. To maintain the effectiveness of the implementation of the policy of strengthening character education (PPK) through five school days in Gresik Regency, the five factors need to be carried out consistently and with a high sense of responsibility.

3. The policy of strengthening character education (PPK) through five school days in Gresik Regency can encourage the willingness and ability/capacity of school institutions to improve the quality of education, 
manifested in the form of revitalizing school-based management, due to the conducive school environment, the fulfillment of resources power according to needs (human resources, budget, infrastructure/equipment), good school relations with parents, community / educational institutions and local education agencies, and schools have a comprehensive curriculum - cognitive, psychomotor and affective domains are applied proportionally, there is no tracking in the learning process at school. By increasing the capacity of school institutions, it can increase family/parent awareness about the importance of parenting in harmony with the school. And the community gets quality education services. This illustrates that the quality of the implementation of the policy of strengthening character education(PPK)through five school days in Gresik Regency can be accepted by the community, is considered very good and runs effectively and efficiently although there are still shortages, but not a significant problem and does not affect implementation PPK policy. Thus, the policy of strengthening character education (PPK) through five school days in Gresik Regency empowers school institutions in the delivery of public services in the field of education for the people in their regions, which in turn can improve the quality of education (schools, families, and communities).

\section{SUGGESTION}

As a result of the research, the suggestions put forward by the authors in the following recommendations: The local government / District Education Office of Gresik needs to issue regulations for the implementation of strengthening character education (PPK) through five school days to schools that fulfill the criteria for five working days, and increase the frequency of visits to provide assistance to schools so that school-based management can be maximized, including overseeing the eight of national education standardsto always be fulfilled, and facilitating or intensifying cooperation between schools and businesses in the implementation of strengthening character education (PPK).

Then for schools must always increase resources (human resources, budgets, facilities / infrastructure, information and authority) that are more adequate and representative for the implementation of strengthening character education (PPK) policies, and optimize the functions of the MKKS and MGMP in the implementation of the strengthening character educationprogram, then always encourage the formation of good relations among education staff, educators, students, and the entire school community within the school environment, and also strengthen relationships with school committees or student guardians to create alignment paradigms - strategies for implementing PPK at school and at home.

To all the community become partners and / or volunteers of the school in the implementation of PPK with their respective competencies and professions, and continue to provide an example to the whole school community as an embodiment of the implementation of PPK policy, especially from the business world, it is expected to be more serious in providing opportunities to students to introduce the world of work by aiming to increase the spirit of independence.

And of course, academics should actively give their contribution related to scientific studies in the field of education, especially in the implementation of policies to strengthen character education(PPK)through five school days. It is hoped that the results of the research will be able to explore more concrete steps that have not been revealed so that it can complement the results of the research that has been carried out and as a reference for the government, schools, families, communities in the implementation of strengthening character education(PPK).

\section{REFERENCES}

Afifuddin.,Saebani, B. A. (2009). Qualitative Research Methodology. Bandung: PustakaSetia.

Agustino, Leo. (2016). Fundamentals of Public Policy. Bandung. Alfabeta.

Edwards III, George C. (1980). Implementing Public Policy. Washington, D.C: Congressional Quarterly Press. Government Regulation Number 32 of 2013 concerning Amendments to Government Regulation Number 19 of 2005 concerning National Education Standards. (online), (https://kelembasional.ristekdikti.go.id, accessed, 2016.

Hasbullah, H.M. (2015). Educational Policy in Perspective of Theory, Application, and Objective Conditions of Education in Indonesia. Jakarta: Rajawali Press.

Ibrahim, Amin. (2013). Principles of Public Administration and Implementation (Asep Gunarsa, Ed.). Bandung: Refika Aditama.

Law R.I. Number.20 of 2003 concerning the 2003 National Education System (D. Soemarmo, Ed.). Jakarta: CV Mini Jaya Abadi.

Miller, Johncarlos M. (2016). Stakeholder Perception of an Exemplary Midlle School Character Education Program and Its Implications for School Improvement. Disertasi. the Faculty of The Graduate School at The University of North Carolina at Greensboro.

Miles, M.B. Huberman, A.M., dan Saldana, J. (2014). Qualitative Data Analysis, A Methode Sourbook, Edition 3 
USA: Sage Publication, Terjemahan Tjejep Rohindi Rohidi, UI-Press.

Moleong, Lexy J. (2012). Qualitative Research Methodology.Bandung: PT. Remaja Rosda karya.

Mulyadi, D. (2015). Public Policy and Public Service Studies. Bandung: Alfabeta.

Nugroho, Riant. (2014). Public Policy. Jakarta: Elex Media KomputindoKelompokGramedia. (2008). Public Policy. Jakarta: Elex Media Komputindo. Kelompok Gramedia.

Presidential Regulation of the Republic of Indonesia Number 87 Year 2017 concerning Strengthening Character Education. (on line). (Setkab.goid / wp-content / uploads / 2017/09), accessed 6 September 2017.

Presidential Regulation of the Republic of Indonesia Number 87 Year 2017 concerning Strengthening Character Education. (on line). (Setkab.goid / wp-content / uploads / 2017/09), accessed 6 September 2017.

Purwanto, Ngalim (2008). Administration and Supervision of Education. Bandung: PT RemajaRosdakarya.

Regulation of the Minister of Education and Culture of the Republic of Indonesia Number 20 of 2018

Concerning Strengthening Character Education in Formal Education Units. (online), http://bangpung.blogspot.com), accessed June 20, 2018.

Rusdiana, A. (2015).Educational Policy: From Philosophy to Implementation. Bandung: Pustaka Setia.

Samani, Muchlas, Hariyanto. (2016).character building. Bandung: PT Remaja Rosdakarya.

Sjamsuddin, Sjamsiar. (2006).The Basics and Theories of Public Administration. Malang: Agritek Yayasan Pembangunan Nasional.

Subarsono, AG. (2011).Public Policy Analysis: concepts, theories and applications. Yogyakarta. Pustaka Pelajar. Sugiyono. (2015).Management Research Methods (Setiyawami, Ed.). Bandung: Alfabeta.

Tachjan.(2006).Public Policy Implementation. Bandung: AIPI.

Tilaar, H.A.R., \&Nugroho, R. (2008).Education policy. Yogyakarta: PustakaPelajar.

Widodo, Joko. (2017). Public Policy Analysis: Concepts and Applications of Public Policy Process Analysis (S. Wahyudi., Y Setyorini\&IndroBasuki, Eds.). Malang: Media Nusa Creative.

Winarno, Budi. 2014. Public Policy: Theory, Process and Case Studies. Yogyakarta: Media Pressindo. 